\title{
ANALISIS KADAR KALSIUM (Ca) DAN FOSFORUS (P) PADA LIMBAH SISIK DAN SIRIP IKAN MUJAIR (Oreochromis mossambicus) DARI DANAU LINDU SULAWESI TENGAH
}

\author{
Analysis of Calcium (Ca) and Phosphorus (P) in Waste of Scales and Fins of \\ Mujair Fish (Oreochromis mossambicus) from Lake Lindu in Sulawesi Tengah
}

\author{
* Vanny M. A. Tiwow, Inda Widiarti Hafid, dan Supriadi \\ Pendidikan Kimia/FKIP - Universitas Tadulako, Palu - Indonesia 94118 \\ Received 02 September 2016, Revised 04 October 2016, Accepted 03 November 2016
}

\begin{abstract}
The most fish species live in Lake Lindu is mujair fish with the average number production of 1080 per day. The scales and fins of mujair fish are the biggest waste that is produced from the processing of this fish and they were just thrown away, which can pollute the environment. The aim of this study is to analyze the level of calcium (Ca) and phosphorus $(P)$ on waste of mujair fish (scales and fins) from the lake Lindu as a basic ingredient of a liquid organic fertilizer. Samples of the scales and fins were taken from a seller mujair fish at Touwa street Palu. To analyze the level of calcium $(\mathrm{Ca})$ and phosphorus $(P)$ from the scales and fins was used a Spectro Direct. Based on the results of the analysis, the average of level of calcium $(\mathrm{Ca})$ in the scales and fins was $4.98 \mathrm{mg} / \mathrm{L}$ and $33.33 \mathrm{mg} / \mathrm{L}$, while the average of level of phosphorus (P) was $73.33 \mathrm{mg} / \mathrm{L}$ and $145.33 \mathrm{mg} / \mathrm{L}$. The average concentration of dry weight of Ca in samples of the scales was 3,32 $\mathrm{mg} / \mathrm{kg}$ and the fins was $22,22 \mathrm{mg} / \mathrm{kg}$. The average concentration of the dry weight of $P$ in samples of the scales was 48,88 $\mathrm{mg} / \mathrm{kg}$ and the fins was $96,88 \mathrm{mg} / \mathrm{kg}$. The results of this analysis showed that the highest concentration of calcium $(C a)$ and phosphorus $(P)$ was in the fins of mujair fish.
\end{abstract}

Keywords: Level of calcium (Ca), level of phosphorus (P), scales of mujair fish, fins of mujair fish

\section{Pendahuluan}

Indonesia memiliki 10 danau terbesar salah satunya adalah danau Poso yang merupakan danau terbesar di Sulawesi Tengah. Selain danau Poso, Sulawesi Tengah punya salah satu danau yang sangat potensial yaitu danau Lindu. Danau Lindu terletak di wilayah Taman Nasional Lore Lindu. Secara goegrafis, perairan danau Lindu berada pada posisi $1^{\circ} 03^{\prime}-1^{\circ} 58^{\prime}$ LS, $119^{\circ} 57^{\prime}-120^{\circ} 22^{\prime}$ BT di daerah kecamatan Lindu Kabupaten Sigi Provinsi Sulawesi Tengah, dengan luas perairan $31.000 \mathrm{Ha}$. Di danau Lindu hidup berbagai jenis ikan seperti mujair, ikan mas, lele, gabus, sidat dan lainlain (Baedah, 2010). Penelitian yang telah dilakukan oleh Paudi, dkk., (2007) spesies ikan terbanyak di danau Lindu adalah spesies ikan mujair (Oreochromis mosambicus)

Menurut Baraba \& Choir (1996) dalam ikan mujair terdapat protein dan sedikit lemak

*Correspondence:

Vanny M. A. Tiwow

Program Studi Pendidikan Kimia, Fakultas Keguruan dan

Ilmu Pendidikan, Universitas Tadulako

email: vanny.tiwow@gmail.com

Published by Universitas Tadulako 2016

dari dagingnya dan terdapat zat-zat lain seperti fosfor (P), magnesium (Mg), dan kalsium (Ca) dari duri dan kulitnya (sisik). Menurut Suprihatin (2011) dalam pertumbuhannya tanaman memerlukan tiga unsur hara penting, yaitu kalsium $(\mathrm{Ca})$, fosfor $(\mathrm{P})$, dan kalium (K). Seperti yang telah disebutkan Baraba \& Choir (1996) dan Suprihatin (2011) maka jika dikaitkan unsur yang terdapat pada ikan mujair dengan pertumbuhan tanaman maka dalam ikan mujair terdapat dua unsur yang berperan sebagai unsur hara yaitu kalsium (Ca) dan fosfor (P). Menurut Suprihatin (2011) Kalsium merupakan unsur utama yang diperlukan untuk pertumbuhan dan berfungsinya ujungujung akar. Kalsium didalam tanaman sangat penting untuk menetralisasi senyawa asam. Senyawa asam ini bila konsentrasinya terlalu tinggi, mempunyai pengaruh negatif terhadap tumbuhan. Untuk struktur tanah pertanian sangat penting, bahwa kompleks adsorpsi ionion $\mathrm{Ca}^{2+}$ di dalam air tanah harus cukup tinggi, sedangkan fosfor (P) bertugas mengedarkan energi keseluruh bagian tanaman, berguna 
untuk merangsang pertumbuhan dan perkembangan akar, khususnya akar benih dan tanaman muda. Selain itu, fosfor juga berfungsi sebagai bahan mentah untuk pembentukan sejumlah protein tertentu, membantu asimilasi dan pernapasan, mempercepat pembungaan dan pembuahan, serta mempercepat pemasakan biji dan buah.

Menurut Hakim (2009) pupuk organik cair selain mengandung nitrogen yang menyusun dari semua protein, asam nukleat dan klorofil juga mengandung unsur hara mikro antara lain unsur Mn, Zn, Fe, S, B, Ca dan Mg. Unsur hara mikro tersebut berperan sebagai katalisator dalam proses sintesis protein dan pembentukan klorofil. Menurut Cahyono (2005) tanaman dalam pertumbuhannya memerlukan zat-zat makanan atau unsur hara yang terdiri atas unsur hara makro, seperti N, P, K, S, Mg, Ca dan unsur hara mikro, seperti $\mathrm{Mo}, \mathrm{Cu}, \mathrm{B}, \mathrm{Zn}$, Fe, Mn. Unsur hara makro merupakan unsur hara yang paling banyak diperlukan tanaman dalam pertumbuhannya. Sedangkan unsur hara mikro hanya diperlukan dalam jumlah sedikit oleh tanaman, namun unsur hara mikro harus tetap tersedia di dalam tanah. Sebab, kekurangan salah satu dari unsur hara tersebut tanaman akan menunjukkan gejalah defisiensi sehingga dapat mengganggu pertumbuhannya. Untuk memenuhi zat-zat makanan tersebut, maka diperlukan pemupukan

Pupuk cair mengandung unsur-unsur hara yang dibutuhkan untuk pertumbuhan, perkembangan, kesehatan tanaman. Fosfor (P) berfungsi untuk merangsang pertumbuhan akar buah, dan biji. Manfaat pupuk cair adalah lebih mudah terserap oleh tanaman karena unsurunsur di dalamnya sudah terurai. Tanaman menyerap hara terutama melalui akar, namun daun juga punya kemampuan menyerap hara. Sehingga ada manfaatnya apabila pupuk cair tidak hanya diberikan di sekitar tanaman, tapi juga di atas daun-daun (Santi, 2010).

Penelitian sebelumnya yang dilakukan oleh Trilaksani, dkk., (2006) tentang pemanfaatan limbah tulang ikan tuna (Thunnus sp) sebagai sumber kalsium dengan metode hidrolisis protein. Hasil yang diperoleh dari penelitian yaitu kadar kalsium yang dihasilkan antara 23,72-39,24 (\%bb). Nilai ini masih berada dalam kisaran nilai kadar kalsium yang ditetapkan SNI untuk tepung tulang, yaitu sebesar 30\% (mutu I) dan 20\% (mutu II). Sedangkan untuk nilai rata-rata kadar fosfor yang diperoleh berkisar antara 11,34-14,25 (\%bb).

Penelitian tentang penentuan kadar kalsium pada ikan kering air laut dan ikan kering air tawar dengan metoda spektrofotometri serapan atom. Hasil yang diperoleh kadar kalsium pada ikan kering air laut yaitu ikan teri 756,5 $\mathrm{mg} / 100 \mathrm{~g}$ dan ikan beledang 814,5 mg/100g sedangkan kadar kalsium pada ikan kering air tawar yaitu ikan sepat $1915,5 \mathrm{mg} / 100 \mathrm{~g}$ dan ikan bilih $1377,5 \mathrm{mg} / 100 \mathrm{~g}$. Dari hasil tersebut dapat dilihat bahwa kadar kalsium pada ikan kering air laut lebih rendah dari kadar kalsium ikan kering air tawar (Afrianti \& Harun, 2011)

Pupuk berbahan baku ikan kaya akan unsur makro dan mikro. Pupuk tersebut dilaporkan nyata meningkatkan pertumbuhan beberapa jenis sayuran dengan tingkat penambahan hasil mencapai 60\% dari perlakuan kontrol. Selain sebagai sumber hara, pupuk berbahan baku ikan dilaporkan nyata menurunkan serangan patogen Macrophomina phaseolina, Rhizoctonia solani and Fusarium spp., pada okra dan kacang panjang, serta dapat menginduksi Actynomicetes $s p p$. dan Rhizobacteria spp yang berperan dalam menghasilkan hormon tumbuh disekitar perakaran tanaman (Lestari, dkk., 2011).

Penelitan tentang pengaruh pemberian pupuk cair limbah ikan lemuru (Sardinella $s p)$ dengan dosis yang berbeda terhadap pertumbuhan Chlorella sp. Berdasarkan penelitian yang telah dilakukan maka hasil yang diperoleh pupuk cair limbah ikan lemuru (Sardinella $s p$ ) memiliki kandungan mineral makro seperti nitrogen $(\mathrm{N}) 21 \mathrm{~g} / \mathrm{L}$, fosfor $(\mathrm{P})$ 7,3 g/L dan kalium (K) $13 \mathrm{~g} / \mathrm{L}$, sedangkan kandungan mineral mikro pada pupuk ini adalah kalsium (Ca) sebesar 1,4 g/L, magnesium $(\mathrm{Mg})$ 0,13 g/L, tembaga $(\mathrm{Cu})$ 0,00017 g/L, mangan (Mn) 0,0014 g/L, chlorin (Cl) 0,62 g/L (Meritasari, dkk., 2012).

Ikan mujair di kota Palu banyak dijual di pasar penjualan ikan mujair yang terletak di jalan Touwa dengan produksi rata-rata perhari dapat mencapai 1,080 ekor. Sisik dan sirip ikan mujair merupakan limbah yang banyak dihasilkan dari hasil pengolahan ikan yang hanya terbuang begitu saja, sehingga dapat mencemari lingkungan. Menurut Lestari, dkk., (2011) pemanfaatan ikan sebagai bahan baku pupuk organik cair sudah lama dilakukan. Hingga saat ini telah banyak beredar berbagai jenis pupuk organik berbahan bahan baku ikan, baik sebagai pupuk organik padat maupun 
pupuk organik cair. Namun demikian, pupuk berbahan baku ikan yang telah dikembangkan saat ini umumnya berasal dari ikan berkualitas baik. Sementara disisi lain, limbah ikan tersedia dalam jumlah yang cukup besar dan belum termanfaatkan. Oleh karena itu, sebagai cara untuk mengurangi pencemaran lingkungan yang disebabkan oleh limbah sisik dan sirip ikan mujair yaitu dengan mengubah limbah sisik dan sirip ikan mujair bernilai ekonomis yang dapat dimanfaatkan sebagai bahan dasar pembuatan pupuk organik cair. Tulisan ini mendeskripsikan penelitian tentang analisis kadar kalsium (Ca) dan fosforus (P) pada limbah sisik dan sirip ikan mujair (Oreochromis mossambicus) dari danau Lindu Sulawesi Tengah,

\section{Metode}

\section{Alat dan Bahan}

Alat yang digunakan dalam penelitian ini adalah neraca digital ARC-120, oven MMM Medcenter, tanur FB1410M, dan spektrofotometer Spektro Direct RS232 serial No: 1257060900344.

Bahan yang digunakan dalam penelitian ini adalah limbah sisik dan sirip ikan mujair (Oreochromis mossambicus), aquades, larutan HNO3 pekat (Merck), reagen phosphate 1 dan 2 (Livobond), dan reagen metil petaline $\left(\mathrm{C}_{20} \mathrm{H}_{26} \mathrm{NO}_{3}\right)$ (Livobond).

\section{Prosedur Penelitian \\ Cara Pengambilan Sampel}

Sampel sisik dan sirip ikan mujair diambil dari limbah hasil buangan ikan yang tidak digunakan lagi hanya dibiarkan menumpuk dan membusuk begitu saja dipasar penjualan ikan mujair (Oreochromis mosambicus) yang terletak di jalan Touwa Palu. Ikan mujair yang dijual berasal dari danau Lindu Sulawesi Tengah. Pada proses jual beli berlangsung ikan langsung dibersihkan ditempat tersebut, dimana yang di buang sebagai limbah yaitu sisik, sirip, ekor, dan isi perut ikan. Dari hasil buangan tersebut limbah yang diambil untuk dianalisis dalam penelitian ini adalah sisik dan sirip ikan mujair. Limbah yang diambil \pm 500 gram, kemudian dilakukan analisis.

\section{Penentuan Kadar Air Dan Kadar Abu}

Sampel limbah sisik dan sirip ikan mujair yang telah diambil, dicuci bersih kemudian ditiriskan dan dikeringkan tanpa matahari diangin-anginkan pada suhu kamar, kemudian dimasukkan ke dalam cawan penguap dan ditimbang sebanyak 100 gram, lalu dipanaskan dalam oven pada suhu $105^{\circ} \mathrm{C}$ selama \pm 3 jam. Setelah itu didinginkan dalam desikator dan ditimbang. Kemudian ditentukan kadar airnya dengan rumus sebagai berikut (Sudarmadji, dkk., 1989):

Sampel limbah sisik dan sirip ikan mujair kering ditimbang diperoleh yaitu sisik sebesar 79,54 gram dan sirip sebesar 74,37 gram, lalu sampel limbah sisik dan sirip ikan mujair kering diabukan dalam tanur pada suhu $700^{\circ} \mathrm{C}$ selama \pm 3 jam. Kemudian abu yang diperoleh ditimbang dan ditentukan kadar abunya dengan rumus sebagai berikut (Sudarmadji, dkk., 1989):

\section{Penyiapan Sampel}

Menimbang sampel abu sisik dan sirip ikan mujair, yaitu masing-masing sebanyak 15 gram. Kemudian menambahkan larutan $\mathrm{HNO}_{3}$ pekat sebanyak $20 \mathrm{~mL}$ ke dalam masing-masing sampel, kemudian disaring, hingga terpisah antara filtrat dan residu. Dalam penelitian ini yang diambil hanyalah filtratnya saja sedangkan residunya tidak digunakan. Filtrat yang diperoleh selanjutnya diencerkan dengan aquades dalam labu ukur $100 \mathrm{~mL}$ sampai tanda batas.

\section{Analisis kadar Ca dan kadar P Menggunakan Spectro Direct \\ Analisis Kadar Ca}

Larutan sampel yang sudah siap untuk dianalisis dimasukkan ke dalam vial (tempat sampel berukuran $10 \mathrm{~mL}$ yang bentuknya menyerupai botol). Analisis kadar Ca pada sampel sisik dan sirip ikan mujair dilakukan dengan cara memasukkan masing-masing $10 \mathrm{~mL}$ sampel ke dalam vial, dimana untuk sampel sisik ikan mujair ke dalam 3 buah vial dan sampel sirip ikan mujair juga ke dalam 3 buah vial dan menambahkan reagen (pereaksi) Ca yaitu metil petaline $\left(\mathrm{C}_{20} \mathrm{H}_{26} \mathrm{NO}_{3}\right)$ ke dalam masing-masing vial tersebut, kemudian dikocok sampai pereaksi larut semua menjadi homogen dan larutan berubah warna dari bening menjadi warna merah muda.

\section{Analisis Kadar P}

Menganalisis kadar P pada sampel langkah kerjanya sama dengan menganalisis kadar $\mathrm{Ca}$ hanya saja untuk menganalisis kadar $\mathrm{P}$ menggunakan reagen (pereaksi) yang berbeda yaitu ditambahkan tablet phosphate 1 dan 2 ke dalam vial masing-masing 1 tablet phosphate 1 dan 1 tablet phosphate 2, kemudian dikocok 
sampai pereaksi larut semua menjadi homogen dan terjadi perubahan warna pada larutan sampel dari warna bening menjadi warna biru. Dalam penelitian ini masing-masing sampel sisik dan sirip ikan yang akan dianalisis kadar $\mathrm{Ca}$ dan kadar P dilakukan pengukuran sebanyak 3 kali. Sampel dianalisis menggunakan Spectro Direct, selanjutnya hasil yang diperoleh dirataratakan.

\section{Analisis Data}

Hasil pengukuran yang diperoleh menggunakan alat Spectro Direct, konsentrasi $\mathrm{Ca}$ dan $\mathrm{P}$ dalam ikan mujair (Oreochromis mossambicus) berupa konsentrasi logam dalam larutan sampel $(\mathrm{mg} / \mathrm{L})$. Selanjutnya konversi konsentrasi logam dalam larutan sampel (ppm) menjadi konsentrasi logam berat kering sampel $(\mathrm{mg} / \mathrm{kg})$ dengan menggunakan persamaan berikut: $\mathrm{Y}=\mathrm{V} . \mathrm{X} / \mathrm{m}$ dimana: $\mathrm{Y}=\operatorname{Kadar} \mathrm{Ca}$ dan $\mathrm{P}$ dalam sampel $(\mathrm{mg} / \mathrm{kg}) ; \mathrm{V}=$ Volume penetapan sampel $(\mathrm{L}) ; \mathrm{X}=$ Konsentrasi larutan sampel $(\mathrm{mg} / \mathrm{L}) ; \mathrm{m}=$ Berat sampel kering $(\mathrm{kg})$ (Sudarmadji, dkk., 1989).

\section{Hasil dan Pembahasan}

Analisis kadar air dan kadar abu dalam sampel limbah sisik dan sirip ikan mujair (oreochromis mossambicus) disajikan dalam tabel berikut:

Tabel 1. Data Kadar Air Dan Kadar Abu Dalam Sampel Limbah Sisik Dan Sirip Ikan

Mujair (Oreochromis mossambicus)

\begin{tabular}{ccc}
\hline Sampel & Kadar air & Kadar abu \\
\hline Sisik & $20,46 \%$ & $21,85 \%$ \\
Sirip & $25,63 \%$ & $27,11 \%$ \\
\hline
\end{tabular}

Hasil penelitian ini menunjukkan sisik ikan mujair mempunyai kadar air sebesar 20,46\%. Sedangkan untuk sirip ikan mujair mempunyai kadar air sebesar 25,63\%. Analisis kadar air bertujuan untuk mengetahui seberapa besar kadar air pada sisik dan sirip ikan mujair yang akan dianalisis. Kadar air sampel diperoleh dengan cara berat sampel awal dikurangi dengan berat sampel akhir dan membandingkan dengan berat sampel awal kemudian di kalikan $100 \%$. Hasil ini menunjukkan bahwa kadar air pada sisik dan sirip ikan mujair mencapai $1 / 5$ dari berat sisik dan sirip ikan mujair.

Penentuan kadar abu dalam suatu sampel langkah pertama dalam analisis ini yaitu preparasi sampel. Pada tahap preparasi sampel harus didekstruksi terlebih dahulu. Menurut Lubis (2014) ada dua prosedur yang umum digunakan untuk mendestruksi bahan-bahan organik dalam sampel, yaitu dengan oksidasi basah (wet oksidation) dan pengabuan kering (dry ashing). Dalam penelitian ini dekstruksi sampel menggunakan prosedur pengabuan kering. Fungsi dari destruksi yaitu untuk memutuskan ikatan antara senyawa organik dengan logam yang akan dianalisis.

Kadar abu suatu sampel padat perlu ditentukan untuk melakukan estimasi berapa banyak unsur-unsur anorganik atau mineral yang terkandung dalam sampel. Kadar abu dapat dicari dengan cara mengabukan sampel yang akan di analisis, tetapi sebelumnya sampel dihilangkan airnya terlebih dahulu dikeringkan dalam oven dengan suhu $105^{\circ} \mathrm{C}$. Sampel diabukan dengan cara memanaskan sampel dalam tanur pada suhu $700^{\circ} \mathrm{C}$. Setelah sampel telah menjadi abu, sampel ditimbang. Kadar abu sampel diperoleh dengan cara membandingkan berat abu dengan berat sampel kering di kalikan $100 \%$. Hasil yang diperoleh kadar abu pada sampel sisik ikan mujair yaitu $21,85 \%$ dan sirip ikan mujair yaitu $27,11 \%$. Selanjutnya dilakukan analisis kadar Ca dan P pada limbah sisik dan sirip ikan mujair.

Pengukuran konsentrasi logam dapat dilakukan dengan menggunakan alat Spectro Direct. Jika menggunakan alat Spectro Direct cuplikan suatu sampel yang akan diukur haruslah berupa larutan yang berwarna. Oleh karena itu sampel abu yang diperoleh dari proses pengabuan dilarutkan dengan $\mathrm{HNO}_{3}$ pekat dan dikomplekskan dengan reagen (pereaksi). Sampel yang dapat dianalisis kadar logamnya dengan metode ini hanya sampel yang memiliki warna. Oleh karena itu, untuk sampel yang tidak memiliki warna harus terlebih dulu dibuat berwarna dengan menggunakan reagent spesifik yang akan menghasilkan senyawa berwarna. Reagent yang digunakan harus betul-betul spesifik hanya bereaksi dengan analit yang akan dianalisis. Selain itu juga produk senyawa berwarna yang dihasilkan harus stabil untuk jangka waktu lama (Sastrohamidjojo, 2007). Dalam penelitian ini analisis konsentrasi Ca dikomplekskan dengan metil petaline $\left(\mathrm{C}_{20} \mathrm{H}_{26} \mathrm{NO}_{3}\right)$ dan untuk analisis konsentrasi $\mathrm{P}$ dikomplekskan dengan tablet phosphate 1 dan 2 . Hasil yang diperoleh dari analisis kadar Ca dan P pada limbah sisik dan sirip ikan mujair menggunakan alat Spectro Direct berupa konsentrasi logam dalam larutan sampel (mg/L) selanjutnya dikonversi menjadi 
konsentrasi logam berat kering sampel (mg/ $\mathrm{kg}$ ). Hasil penelitian yang diperoleh disajikan dalam tabel berikut:

Tabel 2. Data Kadar Ca dalam Sampel

Limbah Sisik dan Sirip Ikan Mujair

\begin{tabular}{|c|c|c|c|}
\hline Sampel & Perlakuan & $\frac{\text { Konsentrasi pada }}{\text { sampel (mg/L) }}$ & $\begin{array}{c}\text { Konsentrasi berat } \\
\text { kering sampel (mg/kg) }\end{array}$ \\
\hline \multirow{3}{*}{ Sisik } & I & 4,95 & 3,30 \\
\hline & II & 5 & 3,33 \\
\hline & III & 5 & 3,33 \\
\hline \multicolumn{2}{|c|}{ Rata-rata } & 4,98 & 3,32 \\
\hline \multirow{3}{*}{ Sirip } & I & 33 & 22 \\
\hline & II & 31 & 20,67 \\
\hline & III & 36 & 24 \\
\hline \multicolumn{2}{|c|}{ Rata-rata } & 33,33 & 22,22 \\
\hline
\end{tabular}

Tabel 3. Data Kadar P dalam Sampel Limbah Sisik dan Sirip Ikan Mujair

\begin{tabular}{|c|c|c|c|}
\hline Sampel & Perlakuan & $\begin{array}{c}\text { Konsentrasi pada } \\
\text { sampel (mg/L) }\end{array}$ & $\begin{array}{l}\text { Konsentrasi berat } \\
\text { kering sampel }(\mathrm{mg} / \mathrm{kg})\end{array}$ \\
\hline \multirow{3}{*}{ Sisik } & I & 65 & 43,33 \\
\hline & II & 80 & 53,33 \\
\hline & III & 75 & 50 \\
\hline \multicolumn{2}{|c|}{ Rata-rata } & 73,33 & 48,88 \\
\hline \multirow{3}{*}{ Sirip } & I & 137 & 91,33 \\
\hline & II & 153 & 102 \\
\hline & III & 146 & 97,33 \\
\hline \multicolumn{2}{|c|}{ Rata-rata } & 145,33 & 96,88 \\
\hline
\end{tabular}

Hasil yang diperoleh dari penelitian ini adalah konsentrasi $\mathrm{Ca}$ dalam sampel sisik ikan mujair dengan nilai rata-rata yaitu 4,98 $\mathrm{mg} / \mathrm{L}$ dengan konsentrasi berat kering sampel diperoleh nilai rata-rata yaitu $3,32 \mathrm{mg} / \mathrm{kg}$. Sedangkan dalam sirip ikan diperoleh nilai rata-rata yaitu $33,33 \mathrm{mg} / \mathrm{L}$ dengan konsentrasi berat kering sampel diperoleh nilai rata-rata $22,22 \mathrm{mg} / \mathrm{kg}$. Konsentrasi P dalam sampel sisik ikan mujair diperoleh nilai rata-rata yaitu 73,33 $\mathrm{mg} / \mathrm{L}$ dengan konsentrasi berat kering sampel diperoleh nilai rata-rata yaitu $48,88 \mathrm{mg} / \mathrm{kg}$. Sedangkan dalam sirip ikan diperoleh nilai rata-rata yaitu $145,33 \mathrm{mg} / \mathrm{L}$ dengan konsentrasi berat kering sampel diperoleh nilai rata-rata yaitu $96,88 \mathrm{mg} / \mathrm{kg}$.

Hasil penelitian menunjukkan bahwa kandungan kalsium terbanyak terdapat pada sirip ikan mujair yaitu dengan konsentrasi sampel rata-rata yaitu $33,33 \mathrm{mg} / \mathrm{L}$ dan konsentrasi berat kering sampel rata-rata 22,22 $\mathrm{mg} / \mathrm{kg}$. Selain itu pada sirip ikan mujair juga mengandung fosfor terbesar jika dibandingkan dengan kandungan fosfor yang terdapat pada sisik ikan mujair dengan konsentrasi sampel rata-rata yaitu $145,33 \mathrm{mg} / \mathrm{L}$ dan konsentrasi berat kering sampel rata-rata yaitu $96,88 \mathrm{mg} /$ kg. Sirip merupakan alat tambahan yang berfungsi untuk mengatur kedudukan, gerakan, arah gerakan maupun menjaga keseimbangan pada posisi diam. Letak, ukuran, dan bentuk sirip sangat berhubungan dengan bentuk tubuh secara keseluruhan dan sifat ikan yang bersangkutan. Masing-masing sirip dikontrol oleh serangkaian otot dan didukung pada bagian internal oleh sejumlah jari-jari tulang rawan atau tulang keras (Afrianti \& Harun, 2011).

Hasil yang diperoleh juga menunjukkan bahwa kandungan kalsium lebih banyak terdapat pada sirip ikan mujair dibandingkan pada sisik ikan mujair. Hal ini mungkin disebabkan dalam sirip ikan mujair mengandung tulang rawan dan tulang keras sedangkan sisik ikan mujair tidak.

Tulang ikan banyak mengandung kalsium dalam bentuk kalsium posfat sebanyak $14 \%$ dari total susunan tulang. Bentuk kompleks posfat ini terdapat pada tulang. Unsur utama penyusun tulang ikan adalah kalsium, posfat dan karbohidrat, sedangkan yang terdapat dalam jumlah kecil yaitu magnesium, sodium, sitrat, stronsium, flourida, hidroksida dan sulfat. Dalam proses mineralisasi tulang $\mathrm{Ca}$ dan $\mathrm{P}$ memiliki peran yang penting karena sekitar $80-90 \%$ unsur tulang tersusun dari $\mathrm{Ca}$, P dan Mg (Zainuddin, 2010). Menurut Rocha, dkk., (2014) kalsium dan fosfor berhubungan erat dengan pengembangan kerangka dan pemeliharaan dan mineralisasi tulang.

Kandungan mineral pada ikan tergantung pada spesies, jenis kelamin, siklus biologis, dan bagian tubuh ikan yang dianalisis. Kandungan mineral ikan juga tergantung pada faktor ekologis seperti musim, tempat pengembangan jumlah nutrisi yang tersedia, suhu dan salinitas air. Mineral pada ikan diperlukan untuk menjaga kesehatan tulang, gigi, bahkan sisik. Mineral utama yang diperlukan adalah kalsium dan fosfor. Kalsium dapat dijumpai pada airair berkesadahan tinggi sedangkan fosfor dapat dijumpai pada tanaman air. Didalam ekosistem air terjadi daur fosfor. Fosfat yang terlarut didalam air diserap oleh ganggang dan tumbuhan air. Sedangkan ikan-ikan mendapatkan fosfat melalui rantai makanan (Ye, dkk., 2006). Penelitian lain yang dilakukan oleh Adebayo \& Omitoyin (2013) pada ikan, Ca kompleks dengan $\mathrm{P}$ dalam hidroksiapatit $\left[3 \mathrm{Ca}_{3}\left(\mathrm{PO}_{4}\right) 2 \mathrm{Ca}(\mathrm{OH})_{2}\right]$ berfungsi untuk membentuk kepala, ekor, bahan kristal tulang dan berpartisipasi dalam beberapa proses fisiologi.

Dari hasil analisis yang menunjukkan bahwa dalam limbah sisik dan sirip ikan mujair (Oreochromis mosambicus) terdapat Ca dan P maka dapat disimpulkan bahwa secara ilmiah 
limbah sisik dan sirip ikan mujair (Oreochromis mosambicus) bisa digunakan sebagai bahan dasar pembuatan pupuk organik cair. Hal ini sejalan dengan aturan Food and Agriculture Organization (FAO) yang telah menetapkan kriteria dasar untuk pupuk jenis ikan, yakni kandungan unsur makro harus mempunyai nilai minimal N (12\%), P (8\%), dan K (6\%) disamping kandungan unsur mikro seperti $\mathrm{Ca}$, $\mathrm{Fe}, \mathrm{Mg}, \mathrm{Cu}, \mathrm{Zn}, \mathrm{Mn}$, dan sebagainya (Lestari, dkk., 2011).

\section{Kesimpulan}

Dari hasil penelitian yang telah dilakukan maka dapat disimpulkan bahwa untuk nilai rata-rata konsentrasi $\mathrm{Ca}$ dalam sampel limbah sisik ikan mujair yaitu 4,98 mg/L dan dalam sirip ikan mujair yaitu 33,33 mg/L, sedangkan nilai rata-rata konsentrasi $\mathrm{P}$ dalam sampel sisik ikan mujair yaitu $73,33 \mathrm{mg} / \mathrm{L}$ dan dalam sirip ikan mujair yaitu $145,33 \mathrm{mg} / \mathrm{L}$. Untuk nilai rata-rata konsentrasi berat kering $\mathrm{Ca}$ dalam sampel sisik ikan mujair yaitu $3,32 \mathrm{mg} / \mathrm{kg}$ dan dalam sirip ikan mujair yaitu $22,22 \mathrm{mg} /$ kg. Sedangkan nilai rata-rata konsentrasi berat kering $\mathrm{P}$ dalam sampel sisik ikan mujair yaitu $48,88 \mathrm{mg} / \mathrm{kg}$ dan dalam sirip ikan mujair yaitu $96,88 \mathrm{mg} / \mathrm{kg}$. Dari hasil analisis ini pula ditunjukkan bahwa konsentrasi kalsium $(\mathrm{Ca})$ dan fosfor $(\mathrm{P})$ tertinggi terdapat pada sirip ikan mujair.

\section{Ucapan Terima Kasih}

Penulis mengucapkan terima kasih kepada kepala laboran Kimia FKIP Universitas Tadulako dan semua pihak yang telah membantu dalam pelaksanaan penelitian ini.

\section{Referensi}

Adebayo, I. A. \& Omitoyin, B. O. (2013). Essentiality of calcium supplement in the diets of heterobranchus bidorsalis fingerlings. International Journal of Fisheries and Aquaculture, 5(5), 98-103.

Afrianti, R. \& Harun, S. (2011). Penentuan kadar kalsium pada ikan kering air laut dan ikan kering air tawar dengan metoda spektrofotometri serapan atom. Scentiia, I(2), 18-24.

Baedah, M. A. (2010). Mengelola danau lindu secara bijak. Sulawesi Tengah: Dinas
Kelautan dan Perikanan.

Baraba \& Choir. (1996). Teknik pembenihan dan budi daya mujair. Surabaya: Indah Surabaya.

Cahyono, B. (2005). Tomat budidaya dan analisis usaha tani. Yogyakarta: Kanisus.

Hakim, A. M. (2009). Asupan nitrogen dan pupuk organik cair terhadap hasil dan kadar vitamin $C$ kelopak bunga rosela. Skripsi Program Studi Agronomi Fakultas Pertanian. Surakarta: Universitas Sebelas Maret.

Lestari, I. P., Sastro, Y. \& Irawati, A. F. C. (2011). Kajian teknologi fermentasi limbah ikan sebagai pupuk organik. Jakarta: Balai Pengkajian Teknologi Pertanian

Lubis, D. A. (2014). Akumulasi logam timbal (Pb) dan tembaga ( $\mathrm{Cu}$ ) pada ikan kuniran (upeneus sulphureus) dari perairan estuaria teluk Palu Sulawesi Tengah. Skripsi Program Studi Pendidikan Kimia. Palu: Universitas Tadulako.

Meritasari, D., Mubarok, A. S., Sulmartiwi, L. \& Masithah, E. D. (2012). Pengaruh pemberian pupuk cair limbah ikan lemuru (sardinella sp.) dengan dosis yang berbeda terhadap pertumbuhan chlorella sp. Jurnal Ilmiah Perikanan Dan Kelautan, 4(1), 2732.

Paudi, Ishak, R. \& Hartono, M. (2007). Kelimpahan dan keanekaragaman jenis ikan di perairan Danau Lindu Taman Nasional Lore Lindu Sulawesi Tengah. Skripsi Jurusan Pendidikan Matematika dan Ilmu Pengetahuan Alam. Palu: Universitas Tadulako.

Rocha, C. B., Portelinha, M. K., Fernandes, J. M., Britto, A. C. P., Piedras, S. R. N. \& Pouey, J. L. O. F. (2014). Dietary phosphorus requirement of pejerrey 
fingerlings (odontesthes bonariensis). Trilaksani, W., Salamah, E. \& Nabil, M. Revista Brasileira de Zootecnia, 43(2), 55-59. (2006). Pemanfaatan limbah tulang ikan tuna (thunnus Sp.) sebagai sumber kalsium dengan metode hidrolisis protein. Buletin

Santi, S. S. (2010). Kajian pemanfaatan limbah nilam untuk pupuk cair organik dengan proses fermentasi. Jurnal Teknik Kimia, $4(2), 335-340$.

Teknologi Hasil Perikanan, 9(2), 34-43.

Ye, C. X., Liu, Y. J., Tian, L. X., Mai, K. S., Du, Z. Y., Yang, H. J. \& Niu, J. (2006). Effect of dietary calcium and phosphorus on growth, feed efficiency, mineral content and body composition of juvenil grouper, Epinephelus coioides. Aquaculture, 255,263-271.

Sudarmadji, S., Haryono, B. \& Suhardi. (1989). Analisis bahan makanan dan pertanian (1st ed). Yogyakarta: Universitas dan Gizi UGM.

Suprihatin. (2011). Proses pembuatan pupuk cair dari batang pohon pisang. Jurnal Teknik Kimia, 5(2), 429-433.

Zainuddin. (2010). Pengaruh kalsium dan fosfor terhadap pertumbuhan, efisiensi pakan, kandungan mineral dan komposisi tubuh juvenil ikan kerapu macan (epinephelus fuscoguttatus). Jurnal Ilmu Dan Teknologi Kelautan Tropis, 2(2), 1-9. 